\title{
Research Policy of Tribhuvan. University in a Changed National Context
}

\author{
Krishna Bahadur Thapa
}

According to the Tribhuvan University Act 2016 B.S. the university was established on the 30 th of Asar 2016 B.S. It was the first university of Nepal and thus its importance is obvious in the educational history of modern Nepal. It is evident that prior to the establishment of T.U. no educational institute of Nepal had engaged itself in research activities. Even after the establishment of T.U., it remained as a teaching and affiliating institution for long time. During that period (1960-1973) only a couple of faculty members had earned their Ph.D. degrees from this university. 1 However some research scholarships were created during that period. The above scholarships were intended for conducting research on the poems of King Mahendra Bir Bikram Shah, and on the works of Laxmi Prasad Devkota and Balkrishna Sama.

In the mean time T.U. also installed two other fellowships for doing $\mathrm{Ph}$.D. and research on vedas. Subsequently, two more scholarships were also added to 1t. These were Golchla scholarship and Achyutnath scholarship for Ph.D. and M.A. in economics respectively. 2

Only after the execution of the National Education System Plan (NESP), popularly known as new education system the research activities of T.U. notably extended. Research institute like Institute of Nepalese and Asian Studies and many other research-cum-teaching institutions such as Institute of Humanities and Social Sciences, Institute of Food and Technology and Institute of Business Administration, Commerce and Public Administration were created. The research activities in those institutions were not equal. Institut = like Humanities and Social Science had no separate research wing whereas the Institute of Business Administration Commerce and Public Administration had separate research wing like CEDA (Central for Economic Development and Administration). The present Research Centre known as RECAST (Research Centre for Applied Science and Technology) and CEDA; were then included in the institutions. Only the Research Institute, CNAS was then a purely Research Centre. Thus it seem that the university was not infavour of creating separate Research Centre at that time.

After few years of the execution of new education system plan the steps were taken to create separate research centres. In this connection the Institute of Nepad and Asian Studies was turned into Research Centre for Nepal and Asian Studies (CNAS) on Bhadra 23, 2034 B.S. (September 8 th 1977).3 On that very date the Institute of Applied Science and Technology was also converted into Research Centre for Applied Science

Dr. Thapa is a Reader in History and Chief of Research Division, Tribhuvan University, Kirtipur, Kathmandu, Nepal. 
also removed from the Institute of Business Administration, Commerce, and Public Administration 5 which was dominatingly a teaching institute. Though T.U. has four Research Centres at present, the Research Centre for Education Innovation and Development (CERID) was under the National Education Committee t1ll 1979.6 Thus, to a great extent T.U. adopted the policy of separating. research from teaching. Later experience, however, proved that the policy of T.U. was not sound." It led to the growth of conflict and uncoordinated condition between teaching and research.

Before this, when national education system plan was introduced in the higher education from Shrawan 1, 2030 B.S., T.U. had created a research division at the central level to serve as the Secretariat of Research Coordination Council (RCC) which was formed to coordinate all the researches within T.U. The research division as the secretarlat of T.U., Research Coordination Council was entrusted with many rights and responsbilities on research of T.U. According to the rule of T.U. the following rights and responsibilities have been given to the Research Coordination Council. The Research Division of T.U. as a Secretarfat of RCC is responsible for carrying out them:

1. Determining the research policy of T.U.,

2. Determining the priority field of researches,

3. Planning long term and short term research policy on the development of research standard.

4. Making long term plan to develop the necessary laboratory for the research on science and technology. 7

However these are the recommendatory rights of the RCC, and besides these recommendatory rights the RCC is also given the following other rights and responsibilities: 8

1. Coordinating and supervising all research works within T.U.;

2. Developing the Secretariat of the Council so as to make it the centre of collecting all research information of the nation and disseminating them;

3. Developing academic and research relations with the different research agencies of T.U. and other national and international agencles;

4. Holding research orlented seminars, workshops and orientation programmes in order to make the teachers more research orfented;

5. Evaluating the research programmes proposed by different agencies of T.U.; 
6. Managing the research programes of T.U. research centres in such a way that removes the repetition of researches; and

7. Rendering other necessary advice to the Academic Council of T.U.

After a careful study of the rights and responsibilities of RCC one may come to the ccnclusion that these rights and responsibilities were to a great extent formal rather than mandatory. Moreover the experience uptill now supports the same notion. Besides this, those rights and responsibilities of RCC were either not performed or executed effectively. There were mainly two reasons for 1t. First of all, the rules relating to these rights and responsibilities were not so tight and specific. 9 They do not clearly put the responsibilities on the particular body. In such situation the responsibilities would be shifted or evaded. The same thing happened in executing rules and regulation of T.U. on research matter. Another reason was that the rules and policy formulated by the RCC were not binding to the research centres and they would not cooperate willingly to the RCC in farming and executing uniform research policy. Moreover in those days the executive directors of the research centres were so powerful that some of them virtually dominated T.U. and its authorities. Such directors would not like to be confined by any uniform rules. On the other hand the university authority and the RCC also could not compell them to follow the rules made by them. They even did not like the coordination of RCC on research matter. Such directors, surrounded by very short-sighted persons of the research centres, led the research centres in isolating them from teaching faculties and departments. Thus, they made the research centres more compartmentalized and the accesses of the faculty members were prevented for research activities of the research centres. As a result the researches of the research centres were not in confirmity of the requirements of T.U. The research need would be in one field and the researches would be conducted in other fields. In this way the T.U. did not receive the required output from the researches conducted by the research centres. The researches which have been done, did not support the improvement of teaching and academic quality of T.U.

Besides this the complete separation of the research from teaching created two classes of professionals within T.U. researchers and teachers. The condition was also created according to which those who were researchers were more facilitated. The situation became worse when T.U. with an administrative decision converted the researchers into teachers and made them even readers and professors. It was not done on the basis of their ability and experience of teaching but on the basis of their salary scale. Even after making the research centres separate from teaching and converting researchers into teachers (here note the contradiction that when the research centres were affillated with teaching institutions, there were researchers and when the research centres were separated from teaching institutions the researchers were converted into teachers) the T.U. could not draw due benefit out of $1 t$. Most of the research centres conducted many consultancy and foreign agency funded research projects and drew much money and other benefits from them but the university did not even get the overhead cost from them. Besides the research centres, the researchers involved in such money making 
profects drew undue benefits from the university because the university paid their regular salary at the same time when they were receiving many times higher salary from the project.

All these narrations prove that there was an urgent need to take immediate action on behalf of the university to correct the distortions in the research centres. There was also equally necessary to formulate correct research policy but the university at that time could not take such steps. They could not take such step because of two reasons. First$1 y$, they did not have enough courage to change the "set system" (that might be wrongly set). If they would try to change the "set system" there was a danger of being ousted themselves because we already discussed that some of the executive directors of the research centres at that time were the boss of the authorities. Another reason was that the setting of the system and correcting the wrongs would not have been popular steps at that times because if there would be system, the authorities could not work at their will. No authorfties wanted to be bound by any system.

\section{CHANGED NATIONAL CONTEXT}

As we know the political change took place in Nepal at the end of 2046 B.S. as a result of the great political movement against panchayat system. After the political change, the university also made some strides in bringing changes in the university. The T.U. authorities - ViceChancellor, Rector and Registrar were appointed according to the new changed spirit and the old rules of their appointments were discarded.

After their appointment the new authorities of T.U. took some mafor steps in bringing change according to the new context. They changed the old academic leadership from deans to assistant campus chief level. They also decided to make permanent all those temporary teachers and administrative officials who had served regularly at least a year before Jestha 20,2047 B.S. It was done according to the long pending demand of T.U. Teachers' Assoctation. Moreover, according to the spirit of $10 n g$ and persistent resolution passed by many national convention of T.U. teachers' representatives and forwarded by T.U. Teachers' Association, they also decided to effect time-bound promotion for teachers upto reader's level. Later on when the newly formed T.U. administrative officials union also demanded same promotion criteria for administrative staff, the internal promotion system was evolved upto deputy-administrator's level. Besides those major changes within T.U. many other minor chang ${ }^{p}$ also were brought about so as to meet the changed context of the countrys' political system. Though those steps did not remain broader, uniformal and uncontroversial, they provided a lot of benefit for a large number of teachers and administrative officials.

However no laws, rules and regulations were changed first to bring those changes. A11 those changes were introduced according to the decisions. In the beginning the T.U. authorities did not wait for new T.U. act to bring changes in T.U. On the otherhand whatever the efforts the T.U. authorities made for new T.U. act were not promptly realized by the 
Govermment. The T.U. laws amendment act which was passed in last Marga 2047 B.S. only indorsed the decisions of T.U. taken upto the same month. After the expiry of the amended T.U. act a situation was created where the old rules became effective and the T.U. authorities had to follow them. But those old laws to a large extent were not in accordance to the need of changed condition of T.U. Then the T.U. authorities also were in dilemma. Netther they could defy the old T.U. rules nor they could follow them. As a consequence they kept pending even long pending works and tried for new T.U. act which has not come yet. Where the urgent decision was necessary that was either postponed or made peace-meal decision which developed contradictions, diversities and uncertainty in the decisions making process.

Uptill now, when T.U. has falled to introduce a needful new laws, rules and regulation to meet the demand of changed context, there is a dearth of needful new research policy. All the old rules and regulations the change of research activities are still continuing in $T$.U. Without the change of old rules and regulation, the RCC also could not bring . However, after the change when the new authorities were appointed in the research centres and research division, the RCC also came up with new chairman and members. They from the very beginning tried to bring change in the retakes. policy as to make it more egalitarian and correct the old mistakes. According to this spirit the first meeting (after change) of RCC was held on 15 th Shravan 2047 B.S. After a day long deliberation the meeting ended with the formation of a task force committee comprising nine members including the coordinator.10

The task force comittee held four meetings in different dates. After long discussion, it prepared a small list of suggestions to be placed before the incoming meeting of RCC. Accordingly those suggestions got passed by the meeting of RCC held on 19 th Poush 2047 B.S. The following were the main research policles passed by that meeting: 11

1. Programie in such a way where teachers and researchers' involvement in others field is extended. Such involvement should be arranged on institutional basis.

2. Taking 20-25 percent of overhead cost, from client oriented and forelgn agency funded research projects.

3. Encouraging such research profects which are for the enhancement of teaching, T.U.'s institutional development and T.U. policy matter.

4. Allocating budget for running $\mathrm{Ph} . \mathrm{D}$. programmes.

5. Publishing and disseminating one of the Ph.D. dissertation submitted to T.U.

6. Furnishing informations about all complete and undergoing research profects to Planning Division and Research Division
of T.U. 
These are very little and Insignificant efforts of T.U. Research Coordination Council in bringing a change in the old research policy of T.U. But it should be taken as a beginning. A lot more efforts are st1jl necessary to realize the needs of $T . U$. In the changed context.

\section{Footnotes}

1. Soorya Bahadur Shakya, Establishing and Development of Tr1bhuvan Untversity (1955-1973); Research Division, 1984, p. 79 .

2. Ib1d., Append 1x-U, pp. 355-56.

3. Prayag Raf Sharma, "Research Centre for Nepal and Asian Study (1972-77) A Review", Tribhuvan Univers1ty, an Overview of Its Programme, Research DIvision, T.U., 1978, p. 14.

4. Amir B. Shrestha, "Research Centre for Applied Science and Technology", Tribhuvan University, an Overview of Its Programme, Research Division, T.U., 1978, P. 1 .

5. Madhukar Shamshere Rana, "Centre for Economic Development and Administration", Tribhuvan University an Overview of 1ts Programme, Research Division, T.U., 1978, p. 6 .

6. R.M. Shrestha, M. Shrestha, N.K. Sharma and et al., "Status of Research in T.U!', Research Division, T.U., 1989, p. 3.

7. TrIbhuvan UnIversity Niyamharu (Tribhuvan University Rules), Office of the Executive Council and Senate, Rirtipur, Kathmandu, 2046 B.S. Chapter 44, p. 119.

8. Ib1d., Pp. 119-120.

9. See T.U. rules relating to RCC.

10. Minute of the meeting of the RCC dated 15-4-2047 B.S.

11. Minute of the meeting of the RCC dates 19-9-2047 B.S. 